\title{
Botany, Ethnobotanical Uses, Biological and Chemical Properties of Gethyllis afra L. (Amaryllidaceae)
}

\author{
Collen Musara and Alfred Maroyi ${ }^{*}$
}

\author{
Medicinal Plants and Economic Development (MPED) Research Centre, Department of Botany, University of \\ Fort Hare, Private Bag X1314, Alice 5700, South Africa
}

\begin{abstract}
Gethyllis afra is an important medicinal plant species in South Africa. The current study critically reviewed the botany, ethnobotanical uses, biological and chemical properties of $G$. afra. Information on the botany, ethnobotanical uses, biological and chemical properties of $G$. afra was collected from multiple internet sources which included Scopus, Google Scholar, Elsevier, Science Direct, Web of Science, Pubmed, SciFinder and BMC. Additional information was gathered from pre-electronic sources such as journal articles, scientific reports, books and book chapters obtained from the University library. This study showed that G. afra is mainly used as food, aphrodisiac, and herbal medicine for colic, indigestion, stomach-ache, boils, bruises, insect bites, toothache, convulsions, heart problems and sleeplessness. Major compounds isolated from the fruits of $G$. afra include $\alpha$-pinene, $n$-butyl $n$-butyrate, isoamyl acetate, $\beta$-pinene and 2methylbutyl butyrate. There is need to validate the documented ethnomedicinal uses of $G$. afra through phytochemical and pharmacological studies. Therefore, future studies should focus on these knowledge gaps particularly evaluating the chemical and biological activities of $G$. afra crude extracts and compounds isolated from the species.
\end{abstract}

Keywords: Amaryllidaceae, ethnopharmacology, Gethyllis afra, herbal medicine, South Africa.

\section{INTRODUCTION}

Gethyllis afra L. is a member of the Amaryllidaceae or amaryllis family. Members of the Amaryllidaceae family are known for their horticultural and ornamental appeal as well as for their medicinal properties [1]. The African Amaryllidaceae genera widely used as sources of herbal medicines include Agapanthus L'Hér., Ammocharis Herb., Boophone Herb., Clivia Lindl., Crinum L., Gethyllis L. and Scadoxus Raf. [2-13]. The Amaryllidaceae alkaloids are currently the primary sources of galanthamine which is widely used in the symptomatic treatment of Alzheimer's disease [14]. Research by Nair et al. [1] and Takos and Rook [14] showed that species of some of these genera remain a relatively untapped phytochemical source characterized by acetylcholinesterase (AchE) inhibitor properties. Gethyllis is a genus of bulbous plants that are endemic to the semi-arid areas of Botswana, Namibia and South Africa [15-19]. The genus name is derived from the Greek word "gethyon" which means bulb, onion (Allium cepa L.) or leek (Allium ampeloprasum L.) in reference to their resemblance to these taxa that are characterized by long-necked bulb structures with white sheathing tunics that surround the base of the leaves $[20,21]$. In South Africa, Gethyllis species are commonly referred to as 'kukumakranka', 'bramakranka' or 'koekoemakranka' in Afrikaans or

*Address correspondence to this author at the Medicinal Plants and Economic Development (MPED) Research Centre, Department of Botany, University of Fort Hare, Private Bag X1314, Alice 5700, South Africa; Tel: 0027719600326; E-mail: amaroyi@ufh.ac.za
Khoi [22]. These common names translate to "cure for upset stomach" based on 'koekemakranka brandy' regarded as one of the early Cape remedies for colic and indigestion [11,23-25]. According to Liltveld [20], the genus Gethyllis is one of most extraordinary and poorly researched southern African amaryllids.

The genus Gethyllis is comprised of 32 species $[16,17,19,26]$ and has been divided into four groups based on leaf shape, hairiness and the presence or absence of a cataphyll [27]. Similarly, Snijman [19] divided the Gethyllis into three groups based on whether flowers are fleshy or delicate, numbers of anthers, structure of the stigma and style and whether the leaves are smooth or covered with hairs. In South African traditional medicine, species of the genus Gethyllis that are highly valued as sources of herbal medicines and included in a monographic guide of South African medicinal plants written by Van Wyk et al. [11] include G. afra L., G. ciliaris (Thunb.) Thunb. and G. spiralis (Thunb.) Thunb. According to Van Wyk et al. [11], G. afra is included in materia medica of South Africa on the basis that the species is presently one of the best known and most fully understood herbal medicines in the country. The fruits of this species are reported to have commercial potential as digestives and tonics in South Africa [28,29]. Van Wyk [29] argued that the fruits of $G$. afra, G. ciliaris and $G$. spiralis have commercial potential in South Africa in the production of a wide diversity of food products that can be derived from the fruits such as jam, processed into fruit juices, sweets, jellies, liqueurs and novel flavours. Similarly, 
research by Reinsten et al. [30] showed that Gethyllis species, including $G$. afra have commercial potential for the cut flower trade as potted flowers and foliages. Previous research by Van Wyk and Gericke [31], Van Wyk $[28,29]$ and Van Wyk et al. [11] emphasized the importance of species such as $G$. afra as priority plant resources for the future benefit of local communities in southern Africa. It is within this context that the current study was undertaken aimed at reviewing the botany, ethnobotanical uses, biological and chemical properties of $G$. afra.

\section{Description of Gethyllis afra}

Gethyllis afra is endemic to the semi-arid habitats on sandy flats and stony alluvial plains amongst lowland Fynbos vegetation in the Western Cape province of South Africa $[16,18,19,24]$. The species has been recorded in sandveld Namaqualand to Cape Peninsula to near Heidelberg (Figure 1) at an altitude ranging from $75 \mathrm{~m}$ to $200 \mathrm{~m}$ above sea level $[16,18,19,21,32,33]$. Gethyllis afra has an underground water storage bulb that enable the species to survive in the arid west regions of South Africa [34]. The species is characterized by long and fleshy roots. The bulbs of $G$. afra store sufficient reserves to survive the long, dry season in a dormant state but when conditions become favourable they produce leaves [11]. Literature records show that $G$. afra is associated with a single synonym, Gethyllis pusilla Baker [16]. Gethyllis afra is a bulbous geophyte that grows up to $10 \mathrm{~cm}$ to $14 \mathrm{~cm}$ in height with an underground bulb of which the scales form a distinctive neck at ground level $[16,18,19]$. The roots are fleshy, contractile and may be extremely long while some attached to enlarged somewhat rhizomatous basal plates [20]. The leaves are linear and usually 12 to 30 in number, which dry up at flowering. The leaves are usually erect to spreading, spiralled, usually channeled, glabrous or shortly hairy and basal sheath is not prominent. Gethyllis afra is identified by its unusual curled, spiralled grey-green, whorled and helical shapes which develop during the winter months and their often stone-like speckled cataphylls which camouflage themselves in their surrounds $[21,35]$. The cup-shaped flowers are attractive white or pink in colour, keeled with red on reverse which are followed by fragrant club-shaped berries that emerge in midwinter, long after the flowers and leaves have wilted. The berries are fleshy, yellow to red in colour, characterized by powerful sweet and fruity odour, pushed above the ground at the onset of the new growing phase $[18,19]$. It is within the fragrant pulp in which the numerous seeds of $G$. afra are embedded in [11].

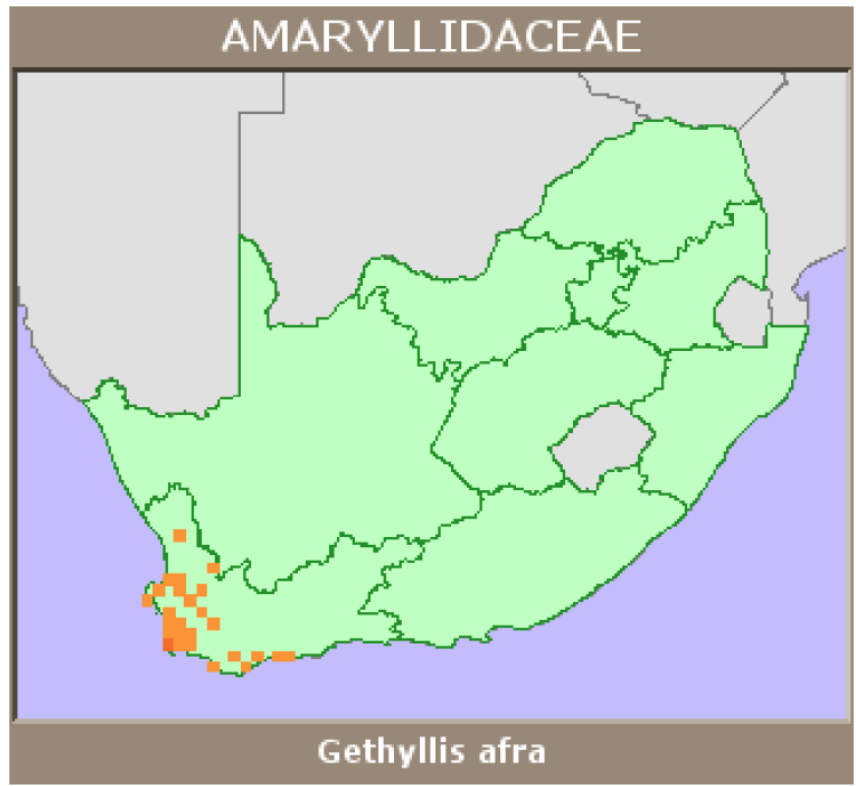

Figure 1: The distribution of Gethyllis afra in South Africa (www.ispotnature.org).

\section{Traditional Uses of Gethyllis afra}

Gethyllis afra is used to cure various ailments and it is a valued medicinal plant species in South Africa $[20,23,31,36-40]$. The aromatic fruits of $G$. afra are steeped in brandy and the infusion traditionally known as "koekemmakranka brandy" is an old Cape remedy for colic and indigestion [31]. Gethyllis afra is traditionally used as remedy for flatulence [23,39], upset stomach and stomach-ache $[36,38]$. Research by Watt and Breyer-Brandwijk [23] showed that the skin of $G$. afra fruits is used as remedy for boils, bruises and insect bites. The flowers are steeped in boiling water and the infusion is given to babies as remedy for teething troubles [36]. The fruit is boiled in water and used as a traditional aphrodisiac by local communities in Namaqualand in South Africa [41]. The flowers are boiled in water and decoction used as a remedy for toothache [41,42]. Research by Thring and Weitz [43] showed that fruits of $G$. afra are used as remedies for convulsions, heart problems, stomach problems and sleeplessness in Bredasdorp and Elim region of the Western Cape province in South Africa.

The ripe fruits of $G$. afra are sweet, juicy, pleasantly aromatic and good to eat $[31,44-46]$. The fruits are highly valued to perfume rooms, cupboards, handkerchiefs and linen in South Africa $[11,23,24,31,40]$. The fruity, sweet flavour and odour associated with the ripe fruits are sometimes used to impart this special aroma to bottles of brandy [31]. The fruits of $G$. afra subsidize to the food and nutritional requirements of local communities in the Western Cape 
province in South Africa through essential nutrients such as vitamins and minerals. Research by Van Wyke and Gericke [31] and Thring and Weitz [43] showed that $G$. afra is propagated on a small scale in Namaqualand in South Africa for the fragrant fruits as well as herbal medicine.

\section{Photochemistry and Pharmacological Properties of Gethyllis afra}

Kamatou et al. [40] identified 43 volatile compounds from fruits of $G$. afra with $\alpha$-pinene $(11.2 \%)$, n-butyl $n$ butyrate $(8.5 \%)$, isoamyl acetate $(8.1 \%), \beta$-pinene $(6.4 \%)$ and 2 -methylbutyl butyrate $(5.8 \%)$ as the main constituents (Table 1). These major constituents may be responsible for the banana, piney or fruity odours associated with the $G$. afra [40]. No alkaloids were detected by gas chromatography-mass spectrometry (GC-MS) in extracts of G. afra [47]. Lack of acetylcholinesterase (AChE) inhibition and affinity to the serotonin reuptake transport protein (SERT) exhibited by $G$. afra extracts could be explained by lack of alkaloids which are considered to be the biological hallmark of the Amaryllidaceae family [47]. The bulbs, flowers, fruits, leaves and roots of two Gethyllis species, G. multifolia L. Bolus and G. villosa (Thunb.) Thunb. showed antioxidant activities [47]. The whole plant extracts of G. multifolia and G. villosa exhibited anti-inflammatory and mutagenic effects [39]. Similarly, methanolic extracts of $G$. multifolia and $G$. villosa exhibited antimicrobial activities [49].

Table 1: Phytochemical Compounds Isolated from Gethyllis afra Fruits by Kamatou et al. [40]

\begin{tabular}{|c|c|}
\hline Composition & Values \\
\hline \hline Benzyl acetate (\%) & 0.6 \\
\hline Benzyl isovalerate (\%) & 0.3 \\
\hline Butyl benzoate (\%) & 0.2 \\
\hline n-Butyl n-butyrate & 8.5 \\
\hline Butyl caprylate (\%) & 0.2 \\
\hline Butyl hexanoate (\%) & 0.2 \\
\hline 1,8-Cineole (\%) & 5.0 \\
\hline Decyl acetate (\%) & 0.2 \\
\hline Ethyl acetate (\%) & 0.7 \\
\hline Ethyl benzoate (\%) & 2.9 \\
\hline Ethyl butyrate (\%) & 2.3 \\
\hline Ethyl hexanoate & 3.6 \\
\hline Ethyl isovalerate (\%) & 2.3 \\
\hline Ethyl octanoate (\%) & 2.0 \\
\hline & \\
\hline & \\
\hline & \\
\hline & \\
\hline & \\
\hline
\end{tabular}

(Table 1). Continued.

\begin{tabular}{|c|c|}
\hline Hexadecane (\%) & 0.1 \\
\hline Hexanol (\%) & 0.2 \\
\hline Hexyl acetate (\%) & 2.5 \\
\hline Hexyl hexanoate (\%) & 0.1 \\
\hline Hexyl-3-methyl butyrate (=Hexyl isovalerate) (\%) & 0.1 \\
\hline Isoamyl acetate $(\%)$ & 8.1 \\
\hline Isoamyl benzoate $(\%)$ & 0.7 \\
\hline Isobutyl benzoate $(\%)$ & 0.4 \\
\hline Isobutyl butyrate (\%) & 3.1 \\
\hline Isobutyl caproate (\%) & 0.7 \\
\hline Isobutyl 3-methyl butyrate (=Isobutyl isovalerate) (\%) & 1.2 \\
\hline Limonene (\%) & 0.5 \\
\hline 2-Methylbutyl butyrate (\%) & 5.8 \\
\hline 2-Methylbutyl isovalerate (\%) & 4.7 \\
\hline 3-Methyl butyl hexanoate (=Isoamyl hexanoate) (\%) & 1.5 \\
\hline Myrcene (\%) & 0.5 \\
\hline Myrtenyl acetate (\%) & 0.1 \\
\hline Neryl isobutyrate (\%) & 0.6 \\
\hline Octanol (\%) & 0.6 \\
\hline Octyl acetate (\%) & 2.7 \\
\hline Octyl 3-methyl butyrate (=Octyl isovalerate) (\%) & 0.2 \\
\hline Pentacosane (\%) & 0.4 \\
\hline$\alpha$-Pinene (\%) & 11.2 \\
\hline$\beta$-Pinene (\%) & 6.4 \\
\hline trans-Pinocarvyl acetate $(\%)$ & 0.2 \\
\hline Terpinen-4-ol (\%) & 0.1 \\
\hline$\alpha$-Terpineol (\%) & 1.6 \\
\hline Verbenone (\%) & 0.1 \\
\hline
\end{tabular}

\section{CONCLUSION}

Based on research carried out by Van Wyk [28] and Van Wyk et al. [11], G. afra is an important herbal medicine that has potential as a source of commercial health and pharmaceutical products. However, results of this review showed that the species has not been exploited to its full potential in terms of primary healthcare of local communities and commercialization of its components as there are several research gaps in terms of its phytochemistry and pharmacological properties. The absence of biological activities of crude extracts or compounds isolated from $G$. afra highlights an existing gap requiring attention from researchers. In addition to cytotoxicity, the plant extracts should be subjected to in vivo acute and sub-chronic toxicity as the importance of evaluating medicinal plants for safety cannot be overemphasized. The development of 
improved herbal medicines, new health promoting or pharmaceutical drugs can only come from linking the scientific tools such as the phytochemistry and biological activities of crude extracts or compounds isolated from the species with ethnomedicinal data. Therefore, future research should focus on evaluating the chemical and biological activities of $G$. afra crude extracts as well as compounds isolated from the species.

\section{AUTHORS' CONTRIBUTIONS}

CM wrote the first draft while AM supervised the research and assisted with writing the manuscript.

\section{CONFLICT OF INTEREST}

No conflict of interest is associated with this work.

\section{ACKNOWLEDGEMENTS}

The authors would like to express their gratitude to the Govan Mbeki Research and Development Centre (GMRDC), University of Fort Hare for financial support to conduct this research.

\section{REFERENCES}

[1] Nair JJ, Bastida J, et al. Alkaloids of the South African Amaryllidaceae: a review. Nat Prod Comm 2013; 8: 1335-50. https://journals.sagepub.com/doi/pdf/10.1177/1934578X1300 800938.

[2] Gelfand M, Mavi S, et al. The traditional medical practitioners in Zimbabwe: his principles of practice and pharmacopoeia. Gweru: Mambo Press; 1985.

[3] Hedberg I, Staugard F. Traditional medicinal plants: traditional medicine in Botswana. Gaborone: Ipeleng; 1989.

[4] Kokwaro JO. Medicinal plants of East Africa. Nairobi: East African Literature Bureau; 1993.

[5] Hutchings $A$, Scott $A H$, et al. Zulu medicinal plants: an inventory. Pietermaritzburg: University of Natal Press; 1996.

[6] Neuwinger HD. African traditional medicine: a dictionary of plant use and application. Stuttgart: Medpharm Scientific Publishers; 2000.

[7] Arnold TH, Prentice CA, et al. Medicinal and magical plants of southern Africa: an annotated checklist. Pretoria: National Botanical Institute; 2002.

[8] Gurib-Fakim A, Brendler T. Medicinal and aromatic plants of Indian Ocean Islands: Madagascar, Comoros, Seychelles and Mascarenes. Stuttgart: Medpharm Scientific Publishers; 2004.

[9] Schmelzer GH, Gurib-Fakim A. Plant resources of tropical Africa 11(1): medicinal plants 1. Wageningen: PROTA Foundation; 2008.

[10] Schmelzer GH, Gurib-Fakim A. Plant resources of tropical Africa 11(2): medicinal plants 2. Wageningen: PROTA Foundation; 2013.

[11] Van Wyk B-E, Van Oudtshoorn B, Gericke N. Medicinal plants of South Africa. Pretoria: Briza Publications; 2013.

[12] Iwu MM. Handbook of African medicinal plants. CRC Press, Boca Raton; 2014.
[13] Van Wyk B-E, Wink M. Medicinal plants of the world. Pretoria: Briza Publications; 2017.

[14] Takos AM, Rook F. Towards a molecular understanding of the biosynthesis of Amaryllidaceae alkaloids in support of their expanding medical use. Int J Mol Sci 2013; 14: 1171341. https://doi.org/10.3390/ijms140611713

[15] Goldblatt P, Manning JC. Cape plants: a conspectus of the Cape flora of South Africa. Cape Town: Strelitzia 9, National Botanical Institute; 2000.

[16] Germishuizen G, Meyer NL. Plants of southern Africa: an annotated checklist. Pretoria: Strelitzia 14, National Botanical Institute; 2003.

[17] Zimudzi C, Archer RH, et al. Synopsis of Amaryllidaceae from the Flora Zambesiaca area. Kirkia 2006; 18(2): 151-68. https://www.jstor.org/stable/23502325

[18] Manning JC, Goldblatt P. Plants of the greater Cape floristic region 1: the core Cape flora. Cape Town: Strelitzia 29, South African National Biodiversity Institute; 2012.

[19] Snijman DA. Plants of the greater Cape floristic region 2: the extra Cape flora. Cape Town: Strelitzia 30, South African National Biodiversity Institute; 2013.

[20] Liltved WR. The Kukumakranka, past and present. Veld FI 1992; 78: 104-6.

[21] Snijman DA. Amaryllidaceae. In: Leistner OA, editor. Seed plants of southern Africa: families and genera. Pretoria: Strelitzia 10, National Botanical Institute; 2000.

[22] Daniels BCW, Rautenbach $\mathrm{F}$, et al. Environmental stress effect on the phytochemistry and antioxidant activity of a South African bulbous geophyte, Gethyllis multifolia L. South African Journal of Botany 2015; 96: 29-36. http://dx.doi.org/10.1016/j.sajb.2014.10.004

[23] Watt JM, Breyer-Brandwijk MG. The medicinal and poisonous plants of southern and eastern Africa: pharmacological effects and toxicology in man and animals. Edinburgh: E \& S Livingstone; 1962.

[24] Forbes VS. Carl Peter Thunberg travels at the Cape of Good Hope 1772-1775. Cape Town: Van Riebeeck Society; 1986.

[25] Du Plessis N, Duncan G. Bulbous plants of southern Africa. Cape Town: Tafelberg Publishers; 1989.

[26] Müller-Doblies D. De liliilloris nolulae. 3. Enumeratio speclerum generum Gethyllis et Apodolirion (Amaryllidaceae). Willdenowia 1986; 15: 465-71. https://doi.org/10.3372/wi.26.2011

[27] Horstmann A. The genus Gethyllus, leaf to leaf, or spiral to spiral account. IBSA Bull 1999; 48: 33-7.

[28] Van Wyk B-E. The potential of South African plants in the development of new medicinal products. S Afr J Bot 2011; 77: 812-29. https://doi.org/10.1016/j.sajb.2011.08.011

[29] Van Wyk B-E. The potential of South African plants in the development of new food and beverage products. S Afr J Bot 2011; 77: 857-68.

https://doi.org/10.1016/j.sajb.2011.08.003

[30] Reinten EY, Coetzee JH, Van Wyk B-E. The potential of South African indigenous plants for the international cut flower trade. S Afr J Bot 2011; 77: 934-46. https://doi.org/10.1016/j.sajb.2011.09.005

[31] Van Wyk B-E, Gericke N. People's plants: a guide to usefu plants of southern Africa. Pretoria: Briza Publications; 2007.

[32] Du Plessis N, Delpierre G. Indigenous flower pride: kukumakranka. Landbouweekblad 1973; 8: 37-9.

[33] Manning J, Goldblatt P, Snijman D. The color encyclopedia of Cape bulbs. Cambridge: Timber Press; 2002.

[34] Daniels CW. A Study of the propagation and cultivation of Gethyllis multifolia and G. villosa. MTech Dissertation. Cape Town: Cape Peninsula University of Technology; 2007. 
[35] Meerow AW, Snijman DA. Amaryllidaceae. In: Kubilzki K, editor. The families and genera of vascular plants, vol 3, flowering plants monocotyledons: Illianae (except Orchidaceae). Berlin: Springer-Verlag, Berlin, 1998; pp. 83110.

[36] Lighton C. The kukumakranka. Veld FI 1992; 78: 100-103. https://hdl.handle.net/10520/EJC113351

[37] Elgorashi EE, Coombes $\mathrm{PH}$, et al. Isoeugenitol, a cyclooxygenase-1 inhibitor from Gethyllis ciliaris. S Afr J Bot 2007; 73: $156-8$.

https://doi.org/10.1016/j.sajb.2006.06.008

[38] Van der Walt P. Koekemakranka. Wild Jag 2003; 4: 16-17.

[39] Elgorashi EE, Van Staden J. Pharmacological screening of six Amaryllidaceae species. J Ethnopharmacol 2004; 90: 2732.

https://doi.org/10.1016/j.jep.2003.09.012

[40] Kamatou GP, Viljoen AM, et al. Head-space volatiles of Gethyllis afra and G. ciliaris fruits ("Kukumakranka"). S Afr J Bot 2008; 74: 768-70. https://doi.org/10.1016/j.sajb.2008.07.002

[41] Rood B. Uit Die Veldapteek. Cape Town: Tafelberg Publishers; 1994.

[42] Louw CAM, Regnier TJC, Korsten L. Medicinal bulbous plants of South Africa and their traditional relevance in the control of infectious diseases. J Ethnopharmacol 2002; 82: 147-54.

https://doi.org/10.1016/S0378-8741(02)00184-8
[43] Thring TS, Weitz FM. Medicinal plant use in the Bredasdorp/Elim region of the southern Overberg in the Western Cape province of South Africa. J Ethnopharmacol 2006; 103(2): 261-75.

https://doi.org/10.1016/.jep.2005.08.013

[44] Fox FW, Norwood Young ME. Food from the veld. Johannesburg: Delta Books; 1982.

[45] Van Wyk B-E, Gorelik B. The history and ethnobotany of Cape herbal teas. S Afr J Bot 2017; 110: 18-38. https://doi.org/10.1016/j.sajb.2016.11.011

[46] Welcome AK, Van Wyk B-E. An inventory and analysis of the food plants of southern Africa. S Afr J Bot 2018, https://doi.org/10.1016/j.sajb.2018.11.003

[47] Bay-Smidt MGK, Jäger AK, et al. Phylogenetic selection of target species in Amaryllidaceae tribe Haemantheae for acetylcholinesterase inhibition and affinity to the serotonin reuptake transport protein. S Afr J Bot 2011; 77: 175-83. https://doi.org/10.1016/j.sajb.2010.07.016

[48] Daniels CW, Rautenbach F, et al. Comparative antioxidantcapacity and -content of leaves, bulbs, roots, flowers and fruit of Gethyllis multifolia L. Bolus and G. villosa Thunb. species. S Afr J Bot 2011; 77: 711-17. https://doi.org/10.1016/j.sajb.2011.03.005

[49] Babajide OJ, Mabusela WT, et al. Phytochemical screening and biological activity studies of five South African indigenous medicinal plants. J Med PI Res 2010; 4: 1924-32. https://doi.org/10.5897/JMPR09.401 